29 th Sample.

Purchased-of Fenning and Hale, 5, Poultry. Price $1 s$.

Of a most unnatural but dull red colour, arising from admixture with an immense quantity of bole Armenian; it contains, moreover, many of the scales of the fish.

\section{0th Sample.}

Purchased-of J. Wingrave and Co., St. Paul's-churchyard. Price 1s. 3d.

Of a vivid and most unnatural red colour, which arises from admixture with a very large quantity of bole Armenian.

\section{1st Sample.}

Purchased-of Thomas Snelling, 30, Fenchurch-street. Price $1 s$.

Of an intense and most unnatural red colour, it being almost saturated with bole Armenian.

\section{$32 n d$ Sample.}

Purchased-of G. Wybrow, 4, Minories. Price Is.

Of a very unnatural red colour. Contains scarcely any muscular fibre, but an immense quantity of bole Armenian. Neither lead nor copper was detected in this or any of the other samples of essence of anchovy.

\section{Freeman's Fish Sadoe. 33rd Sample.}

Purchased-of J. Freeman and Co., 3, Wigmore-street. Price $2 s$.

This sauce is of a pale-brown colour, liquid, and transparent, without a particle of sediment; it contains a very small quantity of mushroom catsup, very much salt, and is flavoured with the juice or essence of the anchovy; it is free from all adulteration, and is certainly a much more pleasant and wholesome sauce than the highly-coloured and adulterated compound ordinarily sold under the misnomer,

"Essence of Anchovies."

The following are the chief results deducible from a consideration of the above table of analyses:-

1st.- That treacle and much salt formed the bases of the five samples of INDIA Sox examined, if they did not even entirely consist of these two ingredients.

2nd.-That in Lazenby's Harvex's Fish SAUCE much oxalate of, lime, and numerous minute chips of charred deal, were detected, the presence of these last aftording some countenance to the inference that they had been used for the purpose of imparting colour to the sauce.

3rd.-That of the seven samples of Tomato SAUCE analyzed, six were artificially coloured, one probably with cochineal and the rest by the addition of considerable quantritres $\delta$ f the ferruginous pigment, bole Armenian.

4th.-That the samples of Essence of LoBsters examined were almost saturated with very large quantities of bole Armenian.

5th.-That the samples of Essexce of Shrimps were saturated to an equal extent with bole Armenian.

6th. That the whole of the samples of ESSENCE OF ANCHOvres analyzed were adulterated with immense quantities of the ferruginous oxide, bole Armenian.

7th. That three of the samples of Essence of Anchovy contained but a small quantity of muscular fibre.

8 th. That two of the samples contained a proportion of flour. -one being a sample of essence of shrimps, and the other of essence of lobster.

9 th. That out of the eighteen RED sauces submitted to examination, no less than sixteen contained bole Armenian, and this usually in immense quantities, far exceeding what was detected in any of the potted meats and fish.

10th. That LEAD, for which separate analyses were made in each case, was not detected in a single instance.

11th. That traces only of COPPER were discovered in some three or four samples.

The above results, then, regarded as a whole, although bad enough, are yet not so bad or serions as the account given by Accum and some other writers, of the adulteration of anchovy paste, \&c., would lead us to infer, since neither lead nor copper was detected in a single instance. Some idea of the quantity of pigment contained in many of the red sauces may be formed, when it is stated that, mixed with turpentine, they might be employed as paints in the priming of doors, windows, \&c.
There is no reason why sauces should be regarded as secret and patent articles; every intelligent cook might readily succeed in preparing all the sauces which are ordinarily required for the table, by the exercise of a very slight amount of reflection and ingenuity. In order to aid such endeavours, we introduce a few receipts of some of the more useful and less known sauces:-

\section{"Tomato Sadok.}

$\begin{array}{llllll}\text { Bruised tomatoes } & \ldots & \ldots & \ldots & \ldots & \text { I gallon }\end{array}$

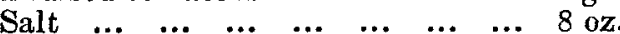

Mix, and after three days squeeze out the juice. To each half-gallon of the juice add, $\begin{array}{lllllllll}\text { Shallots } & \ldots & \ldots & \ldots & \ldots & \ldots & \ldots & 4 \mathrm{oz}\end{array}$ $\begin{array}{llllllll}\text { Black pepper } & . . & \ldots & \ldots & \ldots & \ldots & \ldots & 2 \text { drachms. }\end{array}$

Boil for half an hour, strain, and add,

Mace, allspice, ginger, nutmeg, of each $\quad \ldots \quad \frac{1}{2}$ oz.

Coriander-seed, cochineal, of each $\quad . . \quad$... 22 drachms.

Simmer gently for half an hour, strain, and when cold, bottle it."

Afchovx Sauce.

"Pat ten or twelve anchovies into a mortar, and pound them to a pulp; put this into a very clean iron or well tinned copper saucepan; then put a table-spoonful of cold spring water into the mortar, shake it round, and pour it to the anchovies; set them over or by the side of a gentle fire, and stir them very frequently till they are melted; then add a quarter of a drachm (avoirdupois) of cayenne; let it remain by the fire a few minutes longer; then, while warm, rub it through a hair sieve with the back of a wooden spoon."

\section{Sor.}

"Boil four pounds of the seeds of Dolichos soya with water, until they become soft; then add four pounds of bruised wheat; keep the mixture in a warm place for twenty-four hours; then add four pounds of common salt, and eight pounds of water; put the mixture into a stone jar, and cork it up for two or three months; then press out the liquor. The best soy is imported from China."

\section{Chetney Satce.}

\begin{tabular}{|c|c|c|c|}
\hline ins & $\ldots$ & .. & \\
\hline Sour apples or crabs & $\ldots$ & $\cdots$ & \\
\hline $\begin{array}{l}\text { Brown sugar... } \\
\text { Powdered ginger }\end{array}$ & $\ldots$ & $\ldots$ & \\
\hline $\begin{array}{l}\text { Common salt } \\
\text { Cayenne pepper }\end{array}$ & $\ldots$ & of each & \\
\hline Parlic $\quad \ldots \quad \ldots$ & ... & $\cdots$ & \\
\hline
\end{tabular}

Pound the solid ingredients together in a mortar, adding a little vinegar from time to time, until the whole is reduced to a pulpy mass; then add enough vinegar to reduce it to the consistence of cream, and bottle it for use.

The first, third, and fourth of the above receipts are copied from Gray's Supplement to the Pharmacopœia, edited by Theophilus Redwood; while the second receipt is taken from "The Cook's Oracle."

M. Soyer, in "The Modern Housewife," gives the following account of Chetney:- "Chetney is a production of the East Indies, which, of late years, has come considerably into use; it is made by the mixing together of a variety of fruits, and allowing them to ferment until they become acid; some spices are mixed with them, and they are then bottled for use; the older it is, the better it becomes. That which is made in the Vale of Cashmere is considered the best; it is endeavoured to be imitated in this country, with little success."

\section{POTTED MEATS AND ESSENCE OF ANCHOVY.}

\section{To the Editor of The LANCET.}

SrR,-We observe in your number for Nov.13, that you mention our name, toget her with Messrs. Burgess and $\mathrm{Co}$, Fortnum and Mason, Hedges and Butler, Lazenby and Co., Crosse and Blackwell, and many other most respectable houses, as equally responsible for the coloured admixture in the anchovy paste sold by all alike. We, however, did not sell it as our own make, nor would we knowingly buy or sell any pernicious article whatever, even if marked with the makers' name, as this was. We think it but common justice that the makers, who alone knew the composition, should bear the obloquy. But your remarks on Fish Sauce are much more important in proportion to its greater use. The pure sauce of our own make, 
herewith submitted, would be more sold did not persons through prejudice, as we often find, reject it, and prefer the compound of paint and powdet called essence of anchovies. We remain, Sir, your obedient servants,

Freeman \& Co.

Wigmore-street, Cavendish-square, Nov. 1852.

*.* In the course of our investigations, we have frequently had occasion to refer to the Messrs. Freeman. In the last Report, on "Potted Meats and Fish," we published the results of the analyses of three articles obtained at their establishment, and each of which was ascertained to be highly coloured with the ferruginous oxide, bole Armenian. It was simply stated in each case that the samples were purchased of the Messrs. Freeman, and not that they were the manufacturers of them. On a close examination of the pots, we find at the botiom of two of them, in very small characters, the names of Messrs. "Crosse and Blackwell"-evidently intended as a private mark. We are well aware, as shown by the Report contained in The Lancet of this week, that a pigment is generally employed in the colouring of the sauce called "Essence of Anchovy," but what is the nature of the " powder" used? Will Messrs. Freeman be good enough to furnish us with this information?

\section{fthedical Soctittís.}

\section{ROYAL MEDICAL AND CHIRURGICAL SOCIETY.} Toesdax, Nov. 23, 1852.-Mr. Hodgson, President.

ON The Development of Torul e IN The URINe, aND ON the Relation of these Fungi to Albuminous aND Saccharine Urine. By Dr. A. Hassald.

THE author divided the subject into two parts ; the first comprising the development of certain fungi in urine containing albumen, and the second embraciug the growth of torulæ in saccharine urine. Having quoted from the writings of Drs. Griffith, Owen Rees, and Golding Bird, the several descriptions given by them of torulæ in urine, and which represented the opinions entertained up to this time, he proceeded to quote the opinions of Dr. Bence Jones as to the value of the presence of torulæ, who thought that they were by no means diagnostic of saccharine urine; and the author held that a considerable discrepancy of opinion existed as to the value of the toruly test as indicative of the presence of sugar in the urine. He then described the results of his own observations on the development of these organic forms in the urine. At different periods a number of samples of non-saccharine urine were set aside, some acid, some alkaline, and others albuminous. The changes that ensued were observed and registered from day to day. In a large proportion of the samples, fungi were quickly developed, presenting very distinct and characteristic conditions of development, all of which were after a time ascertained to belong to one and the same species. The author described three distinct stages in the growth of this plant, and he enumerated these separately, under the heads of sporules, thallus, and fructification. Of the sporules two kinds were noticed; the first appeared in a very short space, (regulated much by temperature,) as innumerable minute vesicles or cells, of a globular form, with bright centres and dark outlines with a higher magnifying power, the shaded outline disappeared: the cavities of all were occupied by a fluid containing granules. In a short time the sporules multiplied rapidly, forming distinct circular patches, and ultimately a scum, on the surface of the urine. The elongation of the sporules was not constant, for the development sometimes ceased with the formation of the globular sporules. When the condition of the urine favoured the growth of the fungus, the sporules then quickly elongated themselves, resembling short threads, having rounded extremities; a further elongation took place, and filaments are formed, which consisted of cells placed end to end, and enclosed in a common transparent membrane. From this condition, which is attained by the second day, the fungus passes into the higher state of the thallus. The second kind of sporule, the author designated vesicles; they were much larger than the ordinary sporule, they were globular, and from each proceeded one, two, or three buds, or shoots, which gradually became filaments, at first simple, but ultimately branched forming, as the sporules did, the thallus. In some urines the growth of the fungus went no further than to produce sporules or vesicles; at this point all further development ceased; in others, the growth progressed to the thallus; and in others again, to the complete stage of aerial fructification. The author minutely described these stages, and which were rendered interesting and intelligible by a number of beautifully-executed microscopic drawings of the fungus in its several stages of development. This fungus was developed in twenty-four ont of thirty-two samples of urine; in thirteen, the development did not proceed beyond the stage of sporules; in two, it was arrested in the state of thallus; in the remaining nine it reached the perfect condition of aerial fructification. One of the conditions most favourable to its growth, was a state of acidity of the urine: it was not developed in neutral or alkaline urine, but it appeared alike in albuminous and non-albuminous urine, provided the fluid was acid; and this seemed to be a condition essential to its production. The author then entered upon the inquirywhether this fungus was a new species, or was it identical with one already known and described? He came to the conclusion that it was identical with the well-known Penicilium glaucum, a common fungus, and constantly produced in decaying animal and vegetable matter. The author's conclusions with respect to the development of Penicilium glaucum were, that this fungus was frequently developed in urine; that the conditions necessary for its growth were, animal matter, especially but not exclusively albumen, an acid solution, and oxygen; that it may be developed at will in a variety of animal substances, as in solution of white of egg, acidified with acetic acid; that although the plant does not make its appearance in neutral or alkaline urine, no matter how much albumen be present, yet that it will quickly become developed in these by acidifying such neutral or alkaline solution by acetic, phosphoric, or other acids; that its presence may, to a certain degree, be accepted as an indication of acidity of the urine; that this fungus isno indication whatever of the presence of sugar, nor even of albumen; as a normal quantity of epithelium appears sufficient to induce its growth. - The second part of the paper consisted of an investigation into the development and grow th of torulæ in saccharine urine. Allusion was made to the difference of opinion that prevailed as to the value of the torulø test for sugar in the urine, and the author was desirous of ascertaining whether the torulæ contained in diabetic urine were not characterized by such peculiarites as would constitute a satisfactory test for sugar. Samples of diabetic urine were placed in distinct vessels, some of which were were freely exposed to the air, others in bottles lightly corked, and a third class inclosed in closely-stoppered vessels. A minute description of the changes observed was then recorded; the principal of these were turbidity of the clear urine in two or three hours after being voided, passing into a milky appearance in twenty-four hours cloudy, gelatinous-looking masses appeared, suspended just below the surface; entangled in these masses were bubbles of gas, afterwards proved to be carbonic acid, and separating from time to time, and escaping into the air. By the fifth day the gelatinous masses had disappeared, some having subsided to the bottom, while others had merged into a fawncoloured stratum, floating on the surface, and having the consistence and appearance of beer yeast. This stratum increased in consistence, and formed a coherent layer, presenting on its surface a woolly and flamentous appearance; and, lastly, a crop of delicate, transparent threads became developed on the surface, bearing on their summits minute spherical heads of a black colour. These successive changes were visible to the unassisted eye: but the microscope became necessary to determine what the peculiarities might be, appertaining to these several stages of change. The cloud-like masses were then found to consist of the minute sporules of a fungus embedded in a mucoid base, and these masses constituted the first stage of the development of the fungus. The author then carefully traced the growth of this fungus, from its sporule stage to that of thallus and perfect aerial fructification. (This part of the paper was also illustrated by numerous very carefully executed drawings of the fungus in all its stages of development.) The conclusion derived from this examination of the mode of growth and development of the fungus of saccharine urine was, that it was a very different species from that treated of as the Penicilium glaucum; and further, that a comparison of the diabetic fungus with the yeast plant, showed that the two were identical. The author noticed also the fact that in several samples of urine containing a small quantity of sugar, he had detected much phosphate of lime in a crystallized state. From these investigations the author was led to the following conclusions:-That in saccharine urine, a distinct species of fungus was developed, which was identical with the yeast plant that it passed through three distinct phases of growth, each of which is characteristic of the species: that as it was developed in urine in which the presence of sugar could not be detected 